\title{
Perivascular Epithelioid Cell Tumor of the Kidney: A Rare Case Report
}

\author{
Böbreğin Perivasküler Epiteloid Hücre Tümörü: Nadir Bir Olgu Sunumu
}

\author{
Sedat Karakoç', Serdar Çelik', Ozan Bozkurt' ${ }^{1}$ Ömer Demir' ${ }^{1}$ Aykut Kefi', Güven Aslan', Mustafa Seçil', Burçin Tuna ${ }^{3}$, \\ Kutsal Yörükoğlü ${ }^{3}$, Adil Esen ${ }^{1}$ \\ ${ }^{1}$ Dokuz Eylül University Faculty of Medicine, Department of Urology, Izmir, Turkiye \\ ${ }^{2}$ Dokuz Eylül University Faculty of Medicine, Department of Radiology, Izmir, Turkiye \\ ${ }^{3}$ Dokuz Eylül University Faculty of Medicine, Department of Pathology, Izmir, Turkiye
}

\begin{abstract}
Perivascular epithelioid cell tumors are rare mesenchymal tumors composed of histologically and immunohistochemically distinctive perivascular epithelioid cells. They are mostly benign, however, malignant tumors with aggressive behavior and distant metastasis can also occur. The standard treatment is surgical excision. Here, we report a case of a 25 -year-old male with a $4 \mathrm{~cm}$-mass located in the inferior pole of the left kidney, treated by surgical excision.
\end{abstract}

Keywords: Kidney tumor, perivascular epithelioid cell tumor, partial nephrectomy

Öz

Böbreğin perivasküler epiteloid hücre tümörleri nadir görülen histolojik ve immünohistokimyasal olarak farklı perivasküler epiteloid hücrelerden oluşan mezenkimal tümörlerdir. Çoğunluğu benign tümörlerdir; fakat malign olanları agresif seyredebilir ve metastaza yol açabilir. Standart tedavi yöntemi ise cerrahi eksizyondur. Olgumuzda 25 yaşında sol böbrek alt polünde $4 \mathrm{~cm}$ kitle saptanan ve cerrahi olarak eksize ettiğimiz hastayı sunmayı amaçladık.

Anahtar Kelimeler: Böbrek tümörü, perivasküler epiteloid hücre tümörü, parsiyel nefrektomi

\section{Introduction}

Perivascular epithelioid cell tumors (PEComas) of the kidney are a group of tumor family covering classical angiomyolipoma (AML), microscopic AML (microhamartoma), intraglomerular lesions, cystic $A M L$, epithelioid $A M L$, oncocytoma-like $A M L$ and lymphangiomyomatosis of the renal sinus. The World Health Organization (WHO) defines PEComa as a "mesenchymal tumor that contains perivascular epithelioid cells presenting histological and immunohistochemical differences". While classical AML is benign, epithelioid AMLs are defined as potentially malign mesenchymal lesions for their capacity to develop local recurrence and metastasis $(1,2,3)$. Surgical treatment may be required in AML for symptoms such as hemorrhage and pain, or for the risk of malignancy in tumors that cannot be differentiated from AML in the case of PEComa and certain variants of $\operatorname{AML}(3,4,5)$.
This case report aimed to present a patient who undergone retroperitoneoscopic partial nephrectomy due to a renal mass and diagnosed with PEComa after pathological examination.

\section{Case Presentation}

We planned magnetic resonance imaging (MRI) in a 25-year-old male patient, who was admitted to our clinic due to left-sided flank pain, with no pathological finding during the examination and laboratory tests, however, with a suspicious mass lesion located at the inferior pole of the left kidney detected during ultrasonographic examination. It was decided to perform surgical excision after detection of a $4 \mathrm{~cm}$ tumoral lesion in the inferior pole of the left kidney on MRI (Figure 1). We performed left retroperitoneoscopic partial nephrectomy in our clinic. The total operative time was 90 minutes with the warm ischemia time

Correspondence: Sedat Karakoç MD, Dokuz Eylül University Faculty of Medicine, Department of Urology, İzmir, Turkiye Phone: ++90 2324123450 E-mail: sedatruhi@ hotmail.com ORCID-ID: orcid.org/0000-0002-4725-488X

Received: 09.02.2015 Accepted: 10.05 .2017

Presented in: $11^{\text {th }}$ Urooncology Congress on November 6-10, 2013 as a poster.

Cite this article as: Karakoç S, Çelik S, Bozkurt O, Demir Ö, Kefi A, Aslan G, Seçil M, Tuna B, Yörükoğlu K, Esen A. Perivascular Epithelioid Cell Tumor of the Kidney: A Rare Case Report. J Urol Surg 2017;4:145-148.

๑Copyright 2017 by the Association of Urological Surgery / Journal of Urological Surgery published by Galenos Publishing House. 
of 14.5 minutes. There was no perioperative complication and the patient was discharged on day 3 after removal of the drain given the positive postoperative general status of the patient. The patient was diagnosed with PEComa following human melanoma black-45 (HMB-45) monoclonal antibody expression and 2 mitoses under 50x magnification during pathological examination. 400x magnified images are given in Figure 2, 3, 4 with the actin, HMB-45 and haematoxylin and eosin staining

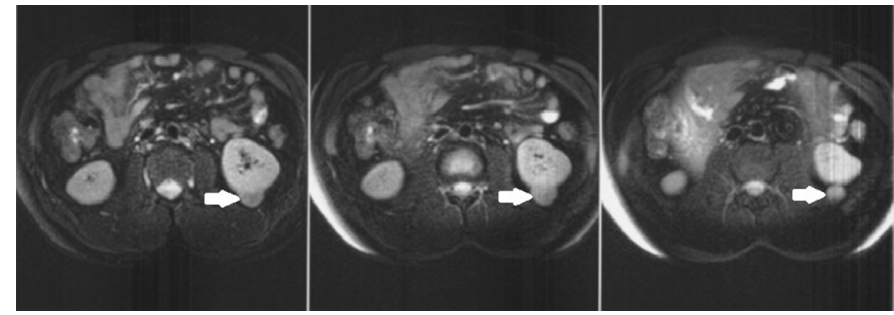

Figure 1. Magnetic resonance imaging image of the $4 \mathrm{~cm}$ tumoral lesion of the patient at the inferior pole of the left kidney

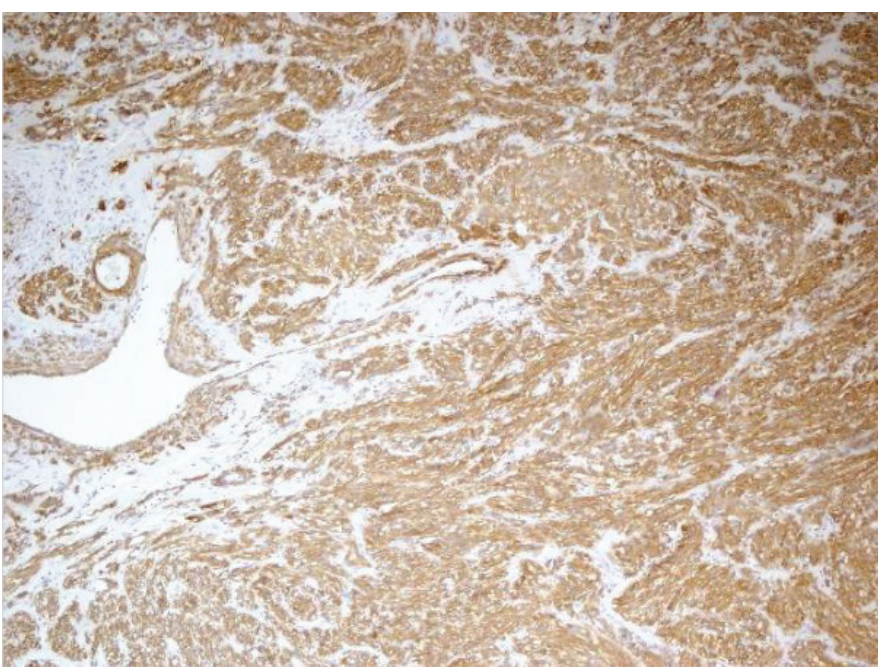

Figure 2. Diffuse actin expression of perivascular epithelioid cell tumor under microscopic immunohistochemical examination (200x magnification)

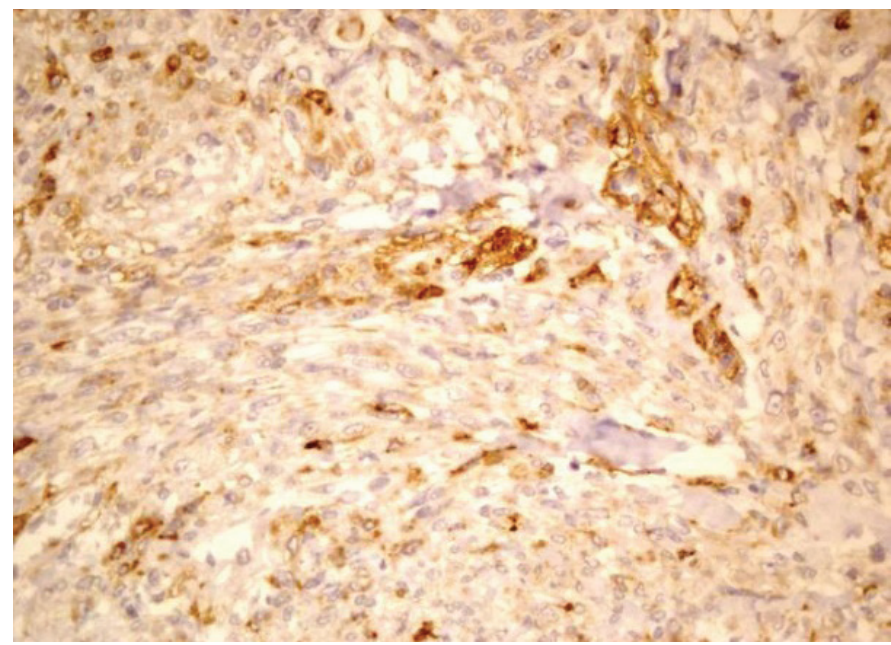

Figure 3. Focal human melanoma black-45 expression of perivascular epithelioid cell tumor under microscopic immunohistochemical examination (400x magnification) of the mass. The surgical margins were negative with no other foci according to the thoracic computed tomography (CT) and abdominal MRI, and the patient is still under follow-up with no local recurrence and metastasis by postoperative month 18 .

\section{Discussion}

The concept of perivascular epithelioid cell first emerged in 1992, which was followed by introduction of the term PEComa 4 years afterwards $(1,6)$. In 2002, the WHO defined PEComa as a mesenchimal tumor that contains perivascular epithelioid cells presenting histological and immunohistochemical differences (7). There is no particular disease-specific complaint of the patient. Patients may present with general symptoms such as nausea, dyspepsia, intermittent pain and loss of appetite. Yet, majority of the patients are asymptomatic. Our case presented with left-sided flank pain. Although there is no specific lab test that may contribute to diagnosis, radiological work-up has limited relevance (6). Studies report several radiological definitions of PEComa's. Some studies present an association between presence of arteriovenous hypervascularity on CT cross-sections and PEComa $(8,9)$. Most of the CT and MRI exams indicate that majority of the lesions are heterogeneous in arterial and venous phases while they are mildly hypodense in the late phase. However, diagnostic accuracy of these methods has been reported to be 15.7-22.7\% (10). Table 1 shows the radiological characteristics of patients diagnosed with PEComa in a study of 32 cases (4). The table also presents radiological characteristics of AML types $(11,12,13)$. MRI was used as the imaging modality in our case but it failed to provide a definitive preoperative diagnosis. Differential diagnosis of the tumor significantly depends on its differentiation from AML due to malignancy risk of the tumor $(1,2)$. Presence of fat, a diagnostic finding for AML, may be demonstrated on MRI. Although T1-weighted images provide high signal intensity on the fat tissue, this is not characteristic for AML. Renal cell carcinoma and hemorrhagic

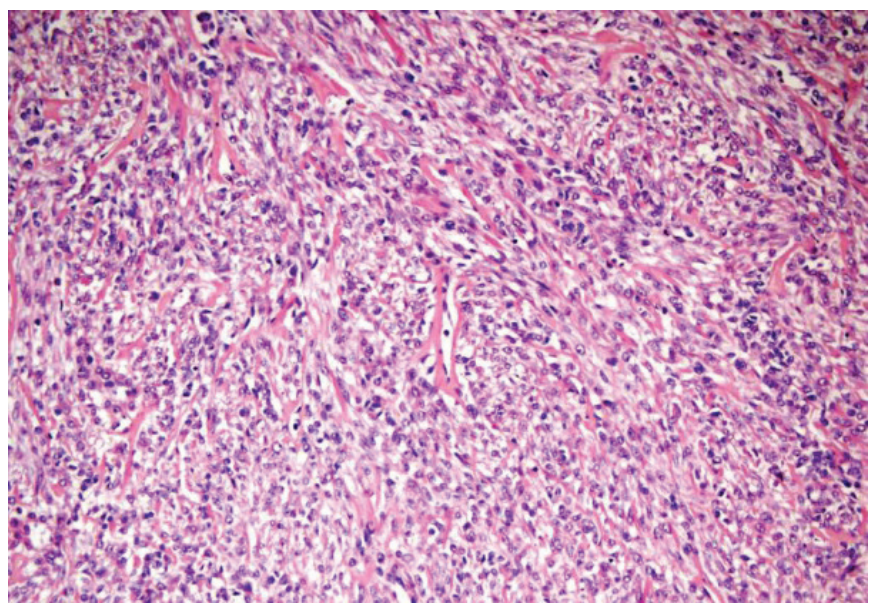

Figure 4. Hematoxylin and eosin staining of perivascular epithelioid cell tumor under microscopic examination (200x magnification) 
Table 1. Radiologic and predictive characteristics for the evaluation of perivascular epithelioid cell tumor-angiomyolipoma $(4,11,12,13)$

\begin{tabular}{|c|c|c|}
\hline & MRI; n (\%) & CT; n (\%) \\
\hline \multicolumn{3}{|l|}{ Tan et al. (4) - PEComa } \\
\hline Hypointense at T1-weighted images and hyperintense and hypodense and isodense at the T2-weighted images & $6 / 15(40)$ & $10 / 32(31.2)$ \\
\hline Well defined margin and a regular shape & $12 / 15(80)$ & $26 / 32(81.2)$ \\
\hline Heterogeneous and significant increase during the arterial and venous phases & 10/15 (66.6) & $21 / 32(65.6)$ \\
\hline \multicolumn{3}{|l|}{ Morosi et al. (11) - AML } \\
\hline Heterogeneous, rich in fat, hyperdense in fat, but hypodense in muscle and intralesional vessel & - & $10(100)$ \\
\hline \multicolumn{3}{|l|}{ Tsukada et al. (12) - epithelioid AML } \\
\hline Heterogeneous & $5 / 8(62.5)$ & - \\
\hline$>45 \mathrm{HU}$ & $6 / 8(75)$ & \\
\hline Solid component and hypointense at T2 & & $3 / 8(37.5)$ \\
\hline Jinzaki et al. (13) - fat poor AML & - & - \\
\hline Absence of fat at CT & & \\
\hline
\end{tabular}

cysts may also present a similar image. Furthermore, chemical shift and india ink artifacts are also used $(3,5,14)$. Indications for surgical treatment in AML are based on recovery of symptoms including hemorrhage and pain, nevertheless surgical treatment may be necessary for pathological definitive diagnosis and treatment due to lack of differentiation of preoperative AML and the risk of malignancy in some variants $(3,5,14)$.

Standard treatment for PEComas is surgical resection involving the healthy tissue. Although many are benign, local recurrences and distant metastasis are also possible; there are even cases where distant metastasis was reported following surgical resection of the primary tumor (15). That is exactly the reason why long-term follow-up of PEComa's is recommended. Some studies reported possible use of positron emission tomography in tumor follow-up (16).

Definitive tumor diagnosis relies on pathologic work-up. Pathologically, PEComas contain epithelial-like cells closely associated with dilated vascular channels. It is the basic feature of cells to have an epithelial cell-like morphology and clear eosinophilic cytoplasm characterized by pre-melanosomes, hemidesmosomes and intensive cytoplasmic glycogen gathered with weak intra-cellular connections. Another important feature is that the tumor presents a melan-A expression that triggers $\mathrm{HMB}-45$, microphthalmia transcription factor and melanocytic differentiation of the tumor $(2,17)$. HMB-45 is the most sensitive melanocytic determinant of PEComa $(2,17)$. Our case showed positive staining of tumor cells, a diffuse staining with actin, desmin and caldesmon and focal with HMB-45 and melan-A. There was no staining with CD117, CD34 and S100.

In PEComas, presence of high mitotic activity [ $>1 / 50$ highpower field (hpf)], atypical mitotic figures, coagulative tumor necrosis, pleomorphism and nuclear atypia, hypercellularity, infiltrative growth pattern, and big tumor size (>70 $\mathrm{mm}$ ) have been shown to be associated with the malignancy potential (17). Our case had 2/50 hpf mitotic activity, a tumor size of 32 $\mathrm{mm}$ but no hemorrhage, necrosis and vascular invasion. Since the patient had only one of the risk factors, i.e., high mitotic activity, the tumor was initially assessed as a benign tumor. Yet, considering the presence of a risk factor and the malignancy potential of the tumor, the patient was put in close follow-up for the possibility of post-resection distant organ metastasis or local recurrence.

In conclusion, what should be kept in mind for the differential diagnosis of PEComa and renal angiolipoma is that these are tumors require close follow-up and good knowledge of pathological risk factors due to their malignancy potential following surgical excision since clinical behavior of these tumors is not precisely known.

\section{Ethics}

Informed Consent: Consent form was filled out by all participants.

Peer-review: External and internal peer-reviewed.

\section{Authorship Contributions}

Surgical and Medical Practices: S.K., S.Ç., Ö.D., A.E., Concept: S.K., O.B., A.K., Design: S.K., G.A., A.K., Data Collection or Processing: S.K., S.Ç., G.A., A.E., Analysis or Interpretation: S.K., M.S., B.T., K.Y., Literature Search: S.K., S.Ç., Writing: S.K., S.Ç.

Conflict of Interest: No conflict of interest was declared by the authors.

Financial Disclosure: The authors declared that this study received no financial support. 


\section{References}

1. Bonetti F, Pea M, Martignoni G, Zamboni G. PEC and sugar. Am J Surg Pathol 1992;16:307-308

2. Martignoni G, Pea M, Reghellin D, Zamboni G, Bonetti F. PEComas: the past, the present and the future. Virchows Arch 2008;452:119-132.

3. Çelik S, Çömez K, Bozkurt O, Demir Ö, Tuna B, Seçil M, Yörükoğlu K, Çelebi i. Böbreğin Epitelioid Anjiyomiyolipomu: İki Olgu Sunumuve Literatür Derlemesi. Bull Urooncol 2015;14:330-332.

4. Tan $\mathrm{Y}$, Zhang $\mathrm{H}$, Xiao EH. Perivascular epithelioid cell tumour: dynamic CT, MRI and clinicopathological characteristics -- analysis of 32 cases and review of the literature. Clin Radiol 2013;68:555-561.

5. Korğalı $E_{1}$ Ayan $S$. Renal anjiomiyolipomlaragüncel yaklaşım. Bull Urooncol 2010;9:43-46.

6. Zamboni G, Pea M, Martignoni G, Zancanaro C, Faccioli G, Gilioli E, Pederzoli $\mathrm{P}$, Bonetti F. Clearcell "sugar" tumor of the pancreas. A novel member of the family of lesions characterized by the presence of perivascular epithelioid cells. Am J Surg Pathol 1996;20:722-730.

7. Folpe AL. Neoplasms with perivascular epithelioid cell differentiation (PEComas). In: Fletcher CDM, Unni KK, Epstein J, Mertens F. Pathology and genetics of tumours of softtissueand bone. Series: WHO Classification of tumours. Lyon, IARC Press, 2002, pp. 221-222.

8. Högemann D, Flemming $\mathrm{P}$, Kreip $\mathrm{H}$, Galanski M. Correlation of MRI and CT findings with histopathology in hepatic angiomyolipoma. Eur Radiol 2001;11:1389-1395.

9. Yamamoto H, Oda Y, Yao T, Oiwa T, Kobayashi C, Tamiya S, Kawaguchi K, Hino 0, Tsuneyoshi M. Malignant perivascular epithelioid cell tumor of the colon: report of a case with molecular analysis. Pathol Int 2006;56:46-50.
10. Baez JC, Landry JM, Saltzman JR, Qian X, Zinner MJ, Mortelé KJ. Pancreatic PEComa (sugar tumor): MDCT and EUS features. J Pancreas 2009;10:679682

11. Morosi C, Stacchiotti S, Marchianò A, Bianchi A, Radaelli S, Sanfilippo R, Colombo C, Richardson C, Collini P, Barisella M, Casali PG, Gronchi A, Fiore $M$. Correlation between radiological assessment and histopathological diagnosis in retroperitoneal tumors: analysis of 291 consecutive patients at a tertiary reference sarcoma center. Eur J Surg Oncol 2014;40:1662-1670.

12. Tsukada J, Jinzaki M, Yao M, Nagashima Y, Mikami S, Yashiro H, Nozaki M, Mizuno R, Oya M, Kuribayashi S. Epithelioid angiomyolipoma of the kidney: radiological imaging. Int J Urol 2013;20:1105-1111.

13. Jinzaki M, Silverman SG, Akita $H$, Nagashima $Y$, Mikami S, Oya M. Renal angiomyolipoma: a radiological classification and update on recent developments in diagnosis and management. Abdom Imaging 2014;39:588604.

14. Israel GM, Hindman N, Hecht E, Krinsky G. The use of opposed-phase chemical shift MRI in the diagnosis of renal angiomyolipomas. AJR Am J Roentgenol 2005;184:1868-1872.

15. Parfitt JR, Bella AJ, Izawa JI, Wehrli BM. Malignant neoplasm of perivascular epithelioid cells of the liver. Arch Pathol Lab Med 2006;130:1219-1222.

16. Zarbis N, Barth TF, Blumstein NM, Schelzig H. Pecoma of the lung: a benign tumor with extensive 18F-2-deoxy-D-glucose uptake. Interact Cardiovasc Thorac Surg 2007;6:676-678.

17. Folpe AL, Mentzel T, Lehr HA, Fisher C, Balzer BL, Weiss SW. Perivascular epithelioid cell neoplasms (PEComas) of soft tissue and gynecologic origin: a clinicopathologic study of 26 cases and review of the literature. Am J Surg Pathol 2005;29:1558-1575. 